\section{European Bank for Reconstruction and Development (EBRD)}

History. The European Bank for Reconstruction and Development was established in 1991 when communism was collapsing in central and eastern Europe and ex-Soviet countries needed support to nurture a new private sector in a democratic environment.

Activities. The EBRD is the largest single investor in the region and mobilizes significant foreign direct investment beyond its own financing. It is owned by 64 countries and two intergovernmental institutions. But despite its public sector shareholders, it invests mainly in private enterprises, usually together with commercial partners. Today the EBRD uses the tools of investment to help build market economies and democracies in 30 countries from Central Europe to Central Asia.

It provides project financing for banks, industries and businesses, for both new ventures and investments in existing companies. It also works with publicly-owned companies, to support privatization, restructuring of state-owned firms and improvement of municipal services. The EBRD uses its close relationship with governments in the region to promote policies that will bolster the business environment. Respect for the environment is part of the strong corporate governance attached to all EBRD investments.

Organization. All the powers of the EBRD are vested in a Board of Governors, to which each member appoints a governor, generally the minister of finance or an equivalent. The Board of Governors delegates powers to the Board of Directors, which is responsible for the direction of the EBRD's general operations and policies. The President is elected by the Board of Governors and is the legal representative of the EBRD. The President conducts the current business of the Bank under the guidance of the Board of Directors.

Headquarters: One Exchange Square, London EC2A 2JN, UK. Website: http://www.ebrd.com

President: Sir Suma Chakrabarti (India).

Secretary-General: Enzo Quattrociocche (Italy).

\section{European Free Trade Association (EFTA)}

History and Membership. The Stockholm Convention establishing the Association was signed on 4 Jan. 1960 and entered into force on 3 May 1960. Founder members were Austria, Denmark, Norway, Portugal, Sweden, Switzerland and the UK. With the accession of Austria, Denmark, Finland, Portugal, Sweden and the UK to the EU, EFTA was reduced to four member countries: Iceland, Liechtenstein, Norway and Switzerland. In June 2001 the Vaduz Convention was signed. It liberalizes trade further among the four EFTA States in order to reflect the Swiss-EU bilateral agreements.

Activities. Free trade in industrial goods among EFTA members was achieved by 1966. Co-operation with the EU began in 1972 with the signing of free trade agreements and culminated in the establishment of a European Economic Area (EEA), encompassing the free movement of goods, services, capital and labour throughout EFTA and the EU member countries. The Agreement was signed by all members of the EU and EFTA on 2 May 1992, but was rejected by Switzerland in a referendum on 6 Dec. 1992. The agreement came into force on 1 Jan. 1994.
The main provisions of the EEA Agreement are: free movement of products within the EEA from 1993 (with special arrangements to cover food, energy, coal and steel); EFTA to assume EU rules on company law, consumer protection, education, the environment, research and development, and social policy; EFTA to adopt EU competition rules on anti-trust matters, abuse of a dominant position, public procurement, mergers and state aid; EFTA to create an EFTA Surveillance Authority and an EFTA Court; individuals to be free to live, work and offer services throughout the EEA, with mutual recognition of professional qualifications; capital movements to be free with some restrictions on investments; EFTA countries not to be bound by the Common Agricultural Policy (CAP) or Common Fisheries Policy (CFP).

The EEA-EFTA states have established a Surveillance Authority and a Court to ensure implementation of the Agreement among the EFTA-EEA states. Political direction is given by the EEA Council which meets twice a year at ministerial level, while ongoing operation of the Agreement is overseen by the EEA Joint Committee. Legislative power remains with national governments and parliaments.

EFTA has formal relations with several other states. Free trade agreements have been signed with Turkey (1991), Israel and Czechoslovakia (1992, with protocols on succession with the Czech Republic and Slovakia in 1993), Poland and Romania (1992), Bulgaria and Hungary (1993), Estonia, Latvia, Lithuania and Slovenia (1995), Morocco (1997), the Palestine Liberation Organization on behalf of the Palestinian Authority (1998), the former Yugoslav Republic of Macedonia and Mexico (2000), Jordan and Croatia (2001), Singapore (2002), Chile (2003), Lebanon and Tunisia (2004), South Korea (2005), the Southern African Customs Union (2006), Egypt (2007), Canada and Colombia (2008), Albania, the Gulf Co-operation Council and Serbia (2009), Peru and Ukraine (2010), Hong Kong and Montenegro (2011), Bosnia and Herzegovina and Central American States (Costa Rica and Panama) (2013), and Central American States (Guatemala) (2015). Agreements with the countries that have joined the European Union in the meantime have been replaced by the relevant arrangements between the EFTA states and the EU. Negotiations on free trade agreements are ongoing with Algeria, Central American States (Honduras), Georgia, India, Indonesia, Malaysia, the Philippines, Russia, Belarus and Kazakhstan (although as at Feb. 2016 negotiations with these three countries were on hold), Thailand and Vietnam. There are currently Joint Declarations on Co-operation with Mercosur (2000), Mongolia (2007), Mauritius (2009), Pakistan (2012), Myanmar (2013) and Ecuador (2015).

Organization. The operation of the free trade area among the EFTA states is the responsibility of the EFTA Council which meets regularly at ambassadorial level in Geneva. The Council is assisted by a Secretariat and standing committees. Each EFTA country holds the chairmanship of the Council for six months. For EEA matters there is a separate committee structure.

Brussels Office (EEA matters, press and information): 12-16 Rue Joseph II, B-1000 Brussels, Belgium.

Headquarters: 9-11 rue de Varembé, CH-1211 Geneva 20, Switzerland.

Website: http://www.efta.int

Email: mail.gva@efta.int

Secretary-General: Kristinn F. Árnason (Iceland).

Publications. Convention Establishing the European Free Trade Association.EFTA Annual Report (online only)._EFTA Factsheets.-EFTA Bulletin.This is EFTA (annual).-EFTA Commemorative Publications.-EEA Supplements._EFTA Study on Certification and Marks in Europe. 2008.EFTA/EU Statistical Cooperation Handbook. 2011. 